\title{
Effects of Tempering on the Microstructure and Properties of a High-Strength Bainite Rail Steel with Good Toughness
}

\author{
Min Zhu ${ }^{1}$, Guang $\mathrm{Xu}^{1}{ }^{1} * \mathbb{D}$, Mingxing Zhou ${ }^{2}$, Qing Yuan ${ }^{1}$, Junyu Tian ${ }^{1}$ and Haijiang $\mathrm{Hu}^{1}$ \\ 1 The State Key Laboratory of Refractories and Metallurgy, Hubei Collaborative Innovation Center for \\ Advanced Steels, Wuhan University of Science and Technology, Wuhan 430081, China; \\ zhum1218@baosteel.com (M.Z.); 15994235997@163.com (Q.Y.); 13164178028@163.com (J.T.); \\ huhaijiang@wust.edu.cn (H.H.) \\ 2 School of Mechanical and Automotive Engineering, Nanyang Institute of Technology, Nanyang 473004, \\ China; kdmingxing@163.com \\ * Correspondence: xuguang@wust.edu.cn; Tel.: +86-156-9718-0996
}

Received: 5 June 2018; Accepted: 22 June 2018; Published: 25 June 2018

\begin{abstract}
An advanced bainite rail with high strength-toughness combination was produced in a steel mill and the effects of tempering on the microstructure and properties of the bainite rail steel were investigated by optical microscopy, transmission electron microscopy, electron back-scattering diffraction and X-ray diffraction. Results indicate that the tensile strength, elongation and impact toughness were about $1470 \mathrm{MPa}, 14.5 \%$ and $83 \mathrm{~J} / \mathrm{cm}^{2}$, respectively, after tempering at $400{ }^{\circ} \mathrm{C}$ for $200 \mathrm{~min}$. Therefore, a high-strength bainite rail steel with good toughness was developed. In addition, the amount of retained austenite (RA) decreased due to bainite transformation after low-temperature tempering $\left(300^{\circ} \mathrm{C}\right)$ and RA almost disappeared after high-temperature tempering $\left(500^{\circ} \mathrm{C}\right)$. Moreover, as the tempering temperature increased, the tensile strength of the rail head first decreased due to the decreased dislocation density and carbon content in bainite ferrite and the coarseness of bainite ferrite, and then increased because of carbide precipitation at high-temperature tempering. Furthermore, RA played a significant role in the toughness of bainite rail. The elongation and toughness of the rail obviously decreased after tempering at $500{ }^{\circ} \mathrm{C}$ for $200 \mathrm{~min}$ because of the disappearance of RA and appearance of carbides.
\end{abstract}

Keywords: bainite rail; tempering; retained austenite; tensile property; impact toughness

\section{Introduction}

At present, the pearlite rail is widely used in the construction of railways. The strength of pearlite rail steel can be improved to near $1300 \mathrm{MPa}$ by chemical composition optimization and heat treatment [1-3]. This value is close to its upper limit in strength and the toughness of pearlite rail significantly decreases with the increase in strength. In order to meet the demands of the development of high-speed and heavy-loading railways, new-generation rail steels should have higher strength, higher toughness and better wear resistance.

Ultra-fine bainite steel, developed by Bhadeshia and his coworkers, has a good combination of strength and toughness [4,5]. Research on the transformation behavior, microstructure evolution and mechanical property of ultra-fine bainite steels has attracted much attention [6-11]. Ultra-fine bainite rail steel has been developing in recent years. It is reported that the strength, toughness, fatigue life and wear resistance of bainite rail are superior to those of pearlite rail [12-15]. In addition, lower carbon content in bainite rail ensures better welding performance. Therefore, bainite rail steel is a promising substitution for the next generation of rail steels. 
Some researchers focused on the optimization of chemical composition of bainite rail and the microstructure-property relationship in bainite rail [16-19]. Wang et al. [16] designed a bainite rail with the chemical compositions of $0.22 \mathrm{C}-2.0 \mathrm{Mn}-1.0 \mathrm{Si}-0.8 \mathrm{Cr}-0.8(\mathrm{Mo}+\mathrm{Ni})(\mathrm{wt} \%)$. They found that the toughness of bainite rail steel is closely related to the stability of retained austenite $[16,17]$. Gui et al. [18] reported that thin film-like retained austenite plays a significant role on the crack propagation of rolling contact fatigue. Zhang et al. [19] studied the hydrogen embrittlement of bainite rails and their results indicated that the content of hydrogen should be lower than $7 \times 10^{-5} \mathrm{wt} \%$ in order to avoid hydrogen embrittlement.

The residual stress in bainite rail is usually larger than that in pearlite rail. In order to relieve the residual stress and further improve the toughness of bainite rail, tempering is usually necessary treatment. Wang et al. [16] developed a tempered bainite rail steel with tensile strength of $1388 \mathrm{MPa}$. However, the study on the effects of tempering on the microstructure and properties of bainite rail is very limited. More investigations on tempered bainite rail are needed to improve the properties and optimize tempering technology.

Therefore, in the present study, the tempering treatments were conducted and the effects of tempering on the microstructure and properties of the bainite rail were analyzed. A 1500-MPa-grade bainite rail with high strength-toughness combination was developed and produced in the industrial production line.

\section{Materials and Methods}

The chemical compositions of the tested steel are given in Table 1 . The continuously cast billets were heated to $1250{ }^{\circ} \mathrm{C}$ in $210 \mathrm{~min}$. Then, the billets $(200 \mathrm{~mm} \times 380 \mathrm{~mm} \times 7000 \mathrm{~mm})$ were hot rolled to rails on a rail mill in an industrial production line, followed by air cooling (about $0.8^{\circ} \mathrm{C} / \mathrm{s}$ ) to room temperature. The beginning and finishing temperatures of rolling were $1150{ }^{\circ} \mathrm{C}$ and $910{ }^{\circ} \mathrm{C}$, respectively. For tempering experiments, samples $300 \mathrm{~mm}$ long were cut from the hot-rolled rail and the cross-sections of the tempering samples were the same as the rolled rail. The tempering temperatures were set to be $300^{\circ} \mathrm{C}, 350{ }^{\circ} \mathrm{C}, 400^{\circ} \mathrm{C}, 450{ }^{\circ} \mathrm{C}$ and $500{ }^{\circ} \mathrm{C}$, respectively, and the tempering time was $200 \mathrm{~min}$.

Table 1. The chemical compositions of the tested steel (wt \%).

\begin{tabular}{cccccccc}
\hline $\mathbf{C}$ & $\mathbf{S i}$ & $\mathbf{M n}$ & $\mathbf{C r}$ & $\mathbf{N i}$ & $\mathbf{M o}$ & $\mathbf{P}$ & $\mathbf{S}$ \\
\hline 0.224 & 1.534 & 1.601 & 1.508 & 0.411 & 0.372 & 0.011 & 0.002 \\
\hline
\end{tabular}

In order to examine the mechanical property of the rail head, specimens for tensile and V-notched impact tests were cut from as-rolled and tempered rail heads (Figure 1a). The size of tensile sample is shown in Figure $1 \mathrm{~b}$ and sample size for impact tests was $5 \mathrm{~mm} \times 5 \mathrm{~mm} \times 100 \mathrm{~mm}$. The tensile tests were conducted on UH-F500KNI materials testing machine at the speed of $0.1 \mathrm{~s}^{-1}$ and impact tests were carried out at room temperature on ZBC24523 impact tester. Duplicate tests were performed for each specimen to improve the accuracy. The microstructure was observed by optical microscopy (OM, Zeiss, Oberkochen, Germany) and transmission electron microscopy (TEM, JEOL, Tokyo, Japan). Thin foils for TEM observation were cut from the bulk specimens, and then mechanically ground to about $40-\mu \mathrm{m}$ thickness. The specimens were further thinned using a twin-jet electro-polisher with an electrolyte consisting of $10 \mathrm{vol} \%$ perchloric acid and $90 \mathrm{vol} \%$ glacial acetic acid. X-ray diffraction (XRD, Panalytical, Almelo, The Netherlands) was used to determine the volume fraction and carbon content of retained austenite (RA). Electron back-scattering diffraction (EBSD, FEI, Hillsboro, OR, USA) was used to distinguish different phases. 


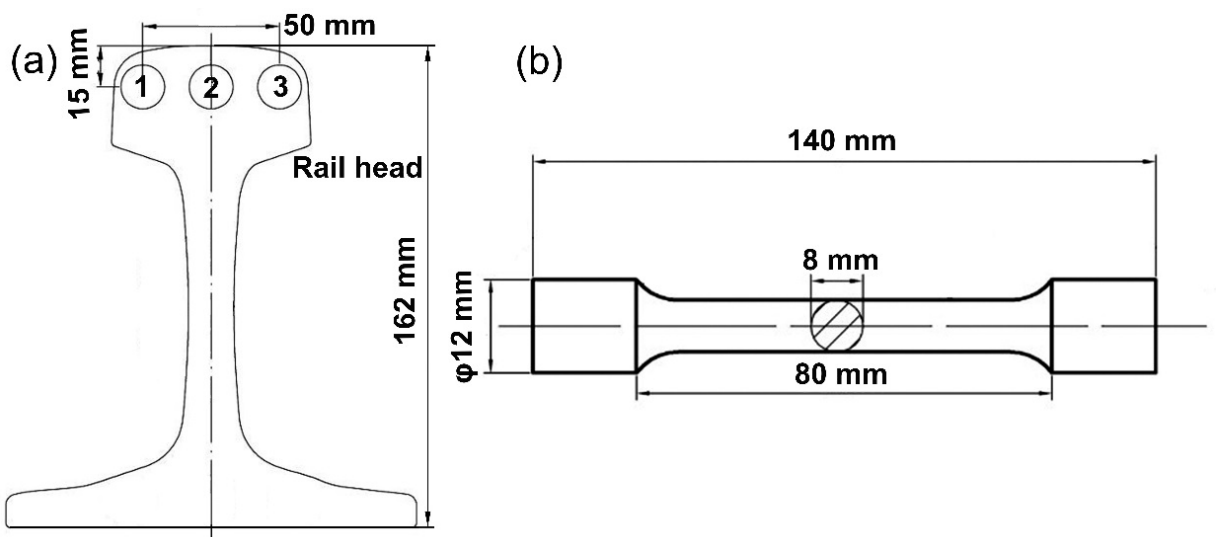

Figure 1. (a) Schematic diagram of samples for tensile and impact tests; (b) tensile sample size.

\section{Results and Discussions}

\subsection{Microstructure}

Figure 2 displays the OM microstructures of as-rolled and tempered rail heads and corresponding EBSD graphs are given in Figure 3. The microstructure consisted of bainite (B) and martensite/austenite (MA) constituent in all samples. Bainite showed lath-like morphology and MA was blocky. It is observed in Figure 2 that compared with hot-rolled bainite rail, when the tempering temperature was lower $\left(300\right.$ to $\left.400{ }^{\circ} \mathrm{C}\right)$, the morphologies of bainite and martensite had no significant change. As the tempering temperature increased, the amount of $\mathrm{M} / \mathrm{A}$ decreased and bainite sheaves became coarser, especially for $500{ }^{\circ} \mathrm{C}$ tempering.

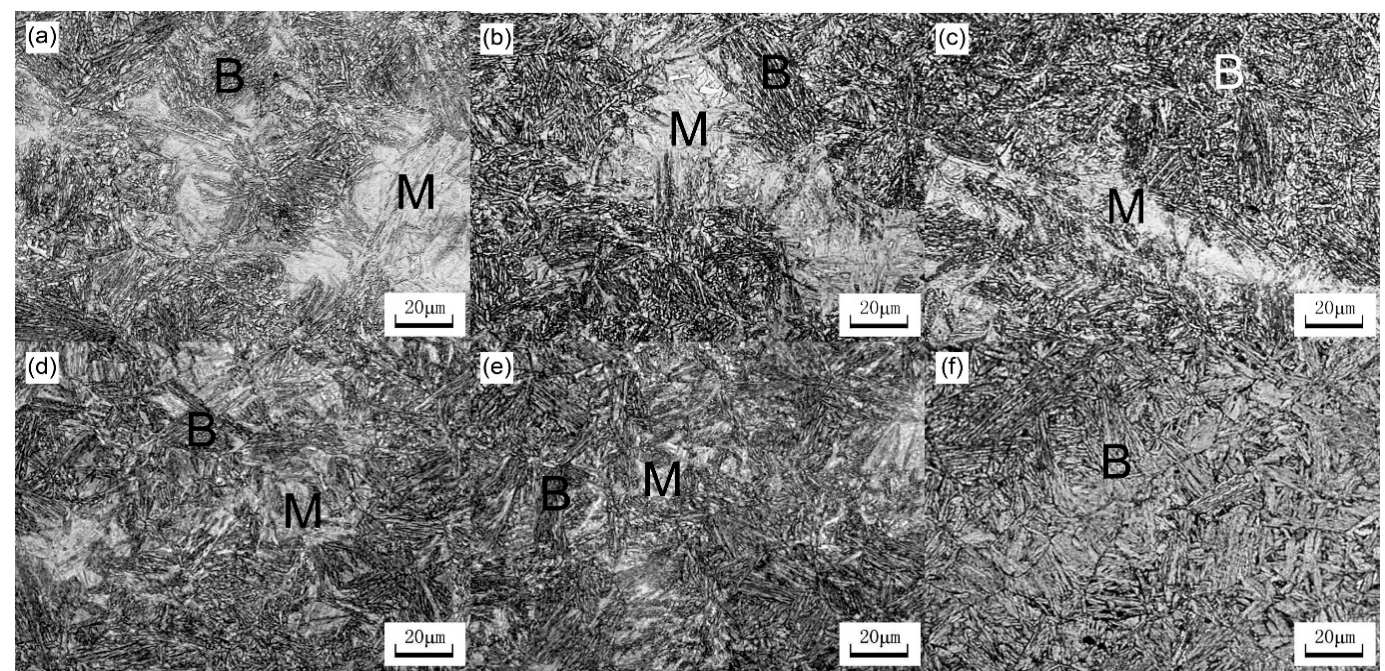

Figure 2. OM microstructures of as-rolled and tempered rail head (a) as-rolled; as-tempered at: (b) $300{ }^{\circ} \mathrm{C}$; (c) $350{ }^{\circ} \mathrm{C}$; (d) $400{ }^{\circ} \mathrm{C}$; (e) $450{ }^{\circ} \mathrm{C}$ and (f) $500{ }^{\circ} \mathrm{C}$.

It was difficult to distinguish RA in the OM micrograph, whereas EBSD graphs (Figure 3) clearly showed the blocky morphology of RA (yellow). It is reported that thin RA films distribute between bainite laths in ultra-fine bainite steels [20,21], but thin RA was hardly observed in EBSD graphs (Figure 3) because of the lower magnification in EBSD graphs. The defect density in bainite is smaller than that in martensite. If two phases are crystallographically similar, but different in defect content, band slope can be used to discriminate phase content based on the database in EBSD analysis software. 
Thus, bainite and martensite with similar lattice structure were distinguished to be red and green in Figure 3 by EBSD.

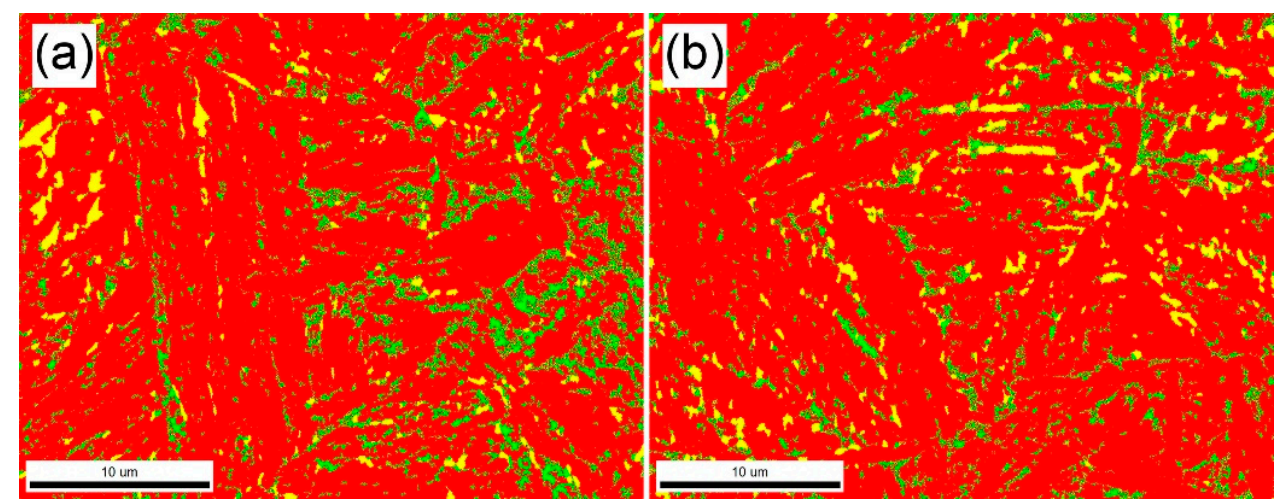

Figure 3. EBSD images showing phase distributions in as-rolled and tempered rails: (a) as-rolled; (b) tempered at $450{ }^{\circ} \mathrm{C}, \mathrm{RA}-\mathrm{yellow}$, bainite-red and martensite-green.

Figures 4-6 exhibit the TEM micrographs of bainite rail steel. Lath-like bainite ferrite (BF), twin martensite (Figure 4c) and M/A were observed in the as-rolled rail. There were many dislocations within the bainite laths (circled area in Figure $4 \mathrm{~b}$ ), which strengthened the bainite structure. When the tempering temperature was lower $\left(300-350{ }^{\circ} \mathrm{C}\right.$, Figure $\left.5 \mathrm{a}, \mathrm{b}\right)$, bainite morphology had no obvious difference from the as-rolled rail. As the tempering temperature increased $\left(400-450{ }^{\circ} \mathrm{C}\right.$, Figure $\left.5 \mathrm{c}, \mathrm{d}\right)$, the dislocation density decreased and the bainite ferrite slightly coarsened. When the tempering temperature was $500{ }^{\circ} \mathrm{C}$, a large amount of carbides separated out (Figure 6). Most carbides precipitated from $\mathrm{M} / \mathrm{A}$, some carbides distributed between bainite ferrite and a small amount of carbides distributed within $\mathrm{BF}$.
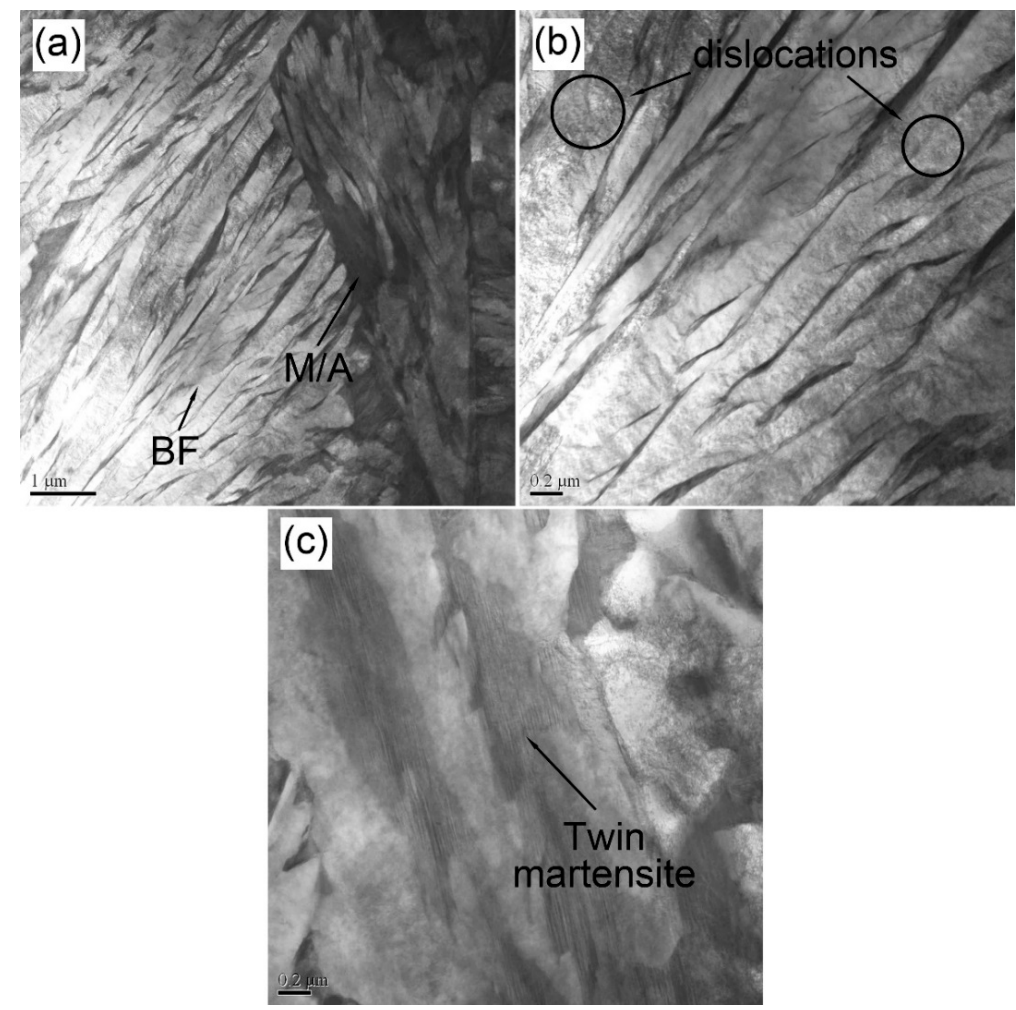

Figure 4. TEM micrographs of as-rolled bainite rail steels. 

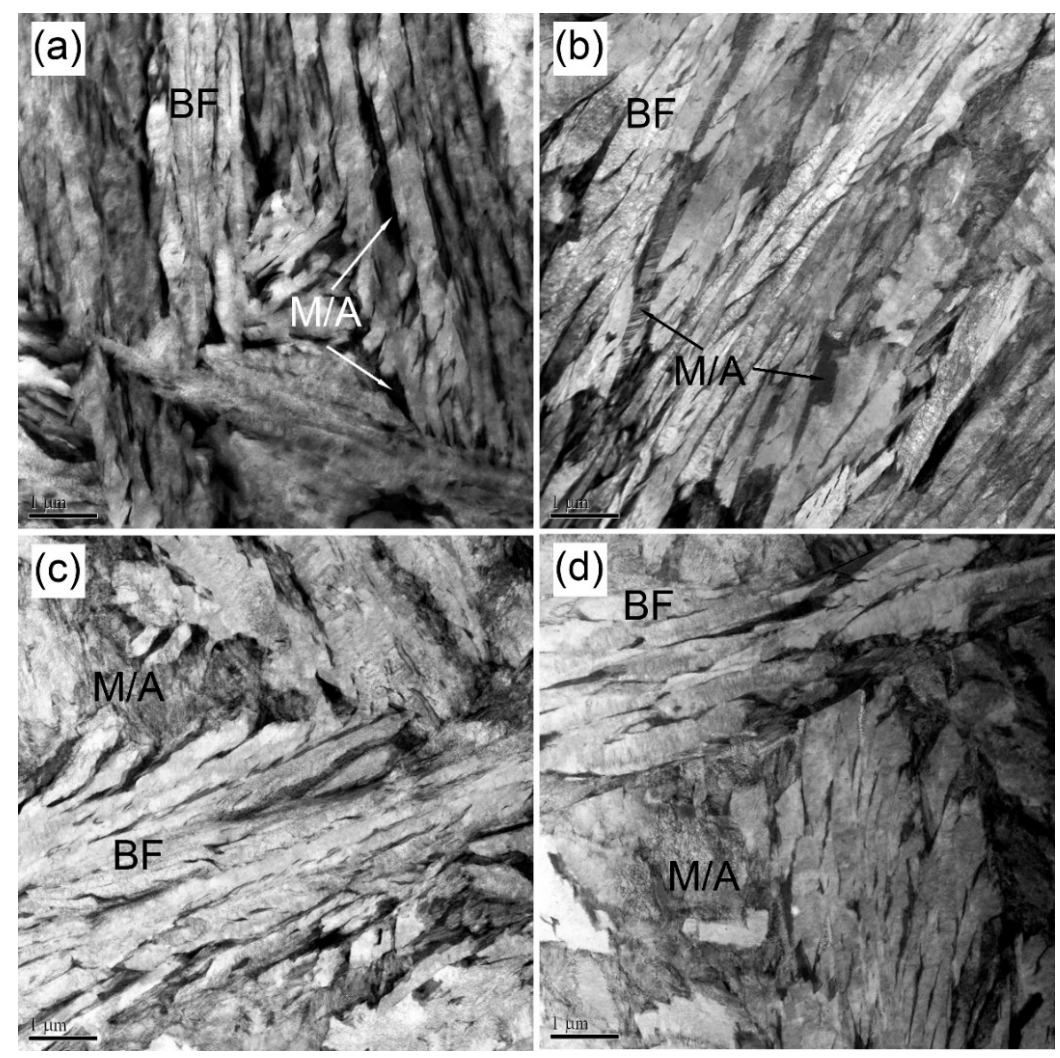

Figure 5. TEM micrographs of tempered bainite rail head tempered at: (a) $300^{\circ} \mathrm{C}$; (b) $350{ }^{\circ} \mathrm{C}$; (c) $400{ }^{\circ} \mathrm{C}$ and (d) $450{ }^{\circ} \mathrm{C}$.
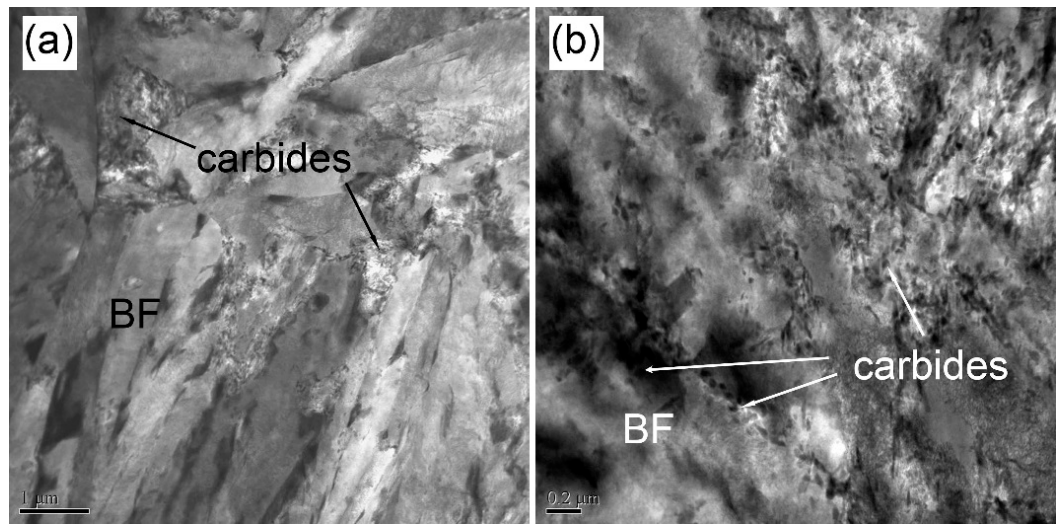

Figure 6. TEM micrographs of bainite rail head tempered at $500{ }^{\circ} \mathrm{C}$.

\subsection{Retained Austenite}

In order to accurately determine the volume fraction of RA, XRD experiments were conducted. Diffraction peaks are shown in Figure 7. The volume fractions of RA $\left(\mathrm{V}_{\mathrm{RA}}\right)$ and the carbon contents in RA $\left(C_{R A}\right)$ were calculated based on the integrated intensities of $(200) \alpha,(211) \alpha,(200) \gamma$, and (220) $\gamma$ diffraction peaks, and the angles of (200) and (220) austenite peaks, respectively, according to the method proposed in Refs. [11,22]. The results are shown in Figure 8a. It is obvious that compared to the as-rolled rail, the RA amount slightly decreased by tempering at low temperatures $\left(300^{\circ} \mathrm{C}\right.$ and $\left.350{ }^{\circ} \mathrm{C}\right)$. Tempering at middle temperature $\left(400^{\circ} \mathrm{C}\right)$ had no significant effect on the RA amount. However, the RA amount in the specimens tempered at high temperatures $\left(450{ }^{\circ} \mathrm{C}\right.$ and $\left.500{ }^{\circ} \mathrm{C}\right)$ decreased, 
and this decrease was evident at $500{ }^{\circ} \mathrm{C}$ (no RA was detected). In general, RA in the tested steel was relatively stable during tempering below $400{ }^{\circ} \mathrm{C}$.

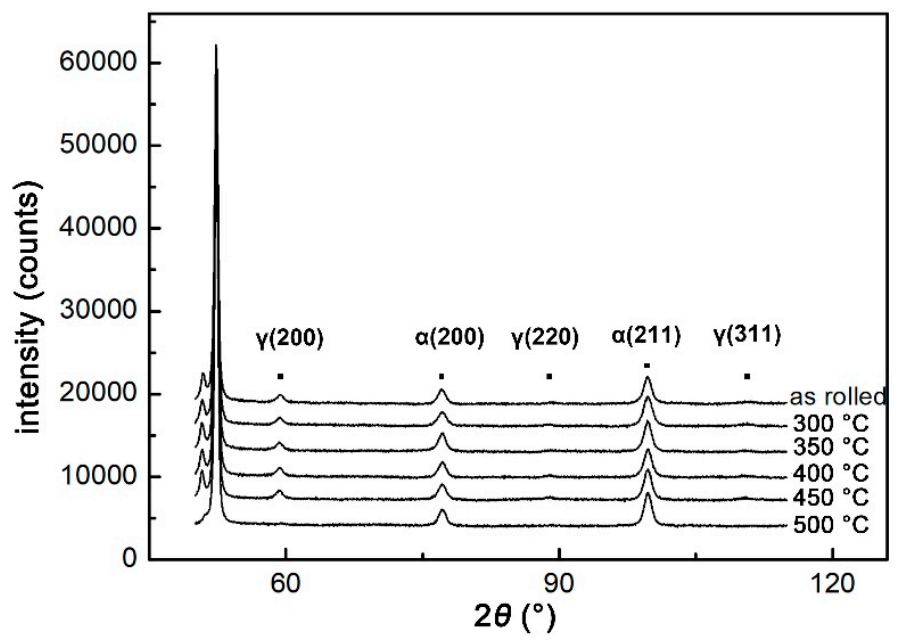

Figure 7. Diffraction peaks in as-rolled and tempered rails.
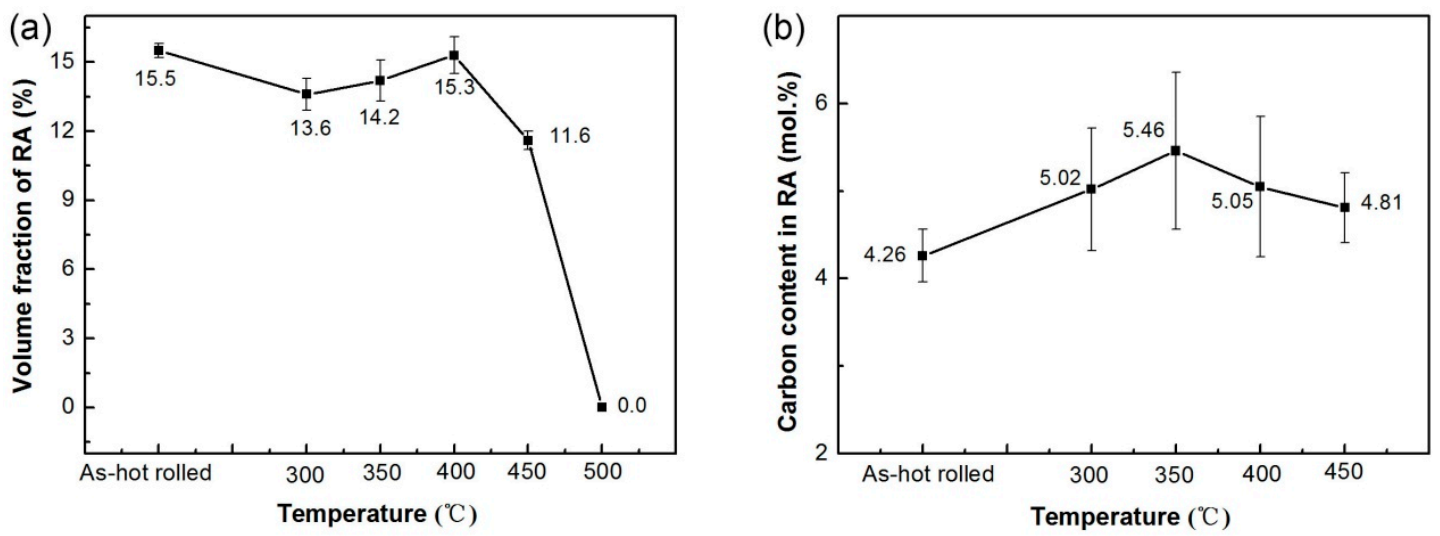

Figure 8. (a) The volume fraction of RA and (b) the carbon content in RA.

It is known that RA may decompose to other microstructures such as ferrite, bainite, martensite and carbides during tempering [23]. The carbon contents in RA were calculated by Equation (1) [16] according to the location of austenite peaks and results are shown in Figure $8 \mathrm{~b}$ :

$$
\alpha_{\gamma}=0.3556+0.00453 x_{\mathrm{c}}+0.000095 \mathrm{x}_{\mathrm{Mn}}+0.00056 \mathrm{x}_{\mathrm{Al}}
$$

where $\alpha_{\gamma}$ is the austenite lattice parameter $(\mathrm{nm})$, and $\mathrm{x}_{\mathrm{c}}, \mathrm{x}_{\mathrm{Mn}}$ and $\mathrm{x}_{\mathrm{Al}}$ are the concentrations of carbon, manganese and aluminum in austenite (wt \%), respectively. The manganese and aluminum concentrations are the original contents in the tested steel. It is noted that the coefficients $(0.000095$ and 0.00056) before $\mathrm{x}_{\mathrm{Mn}}$ and $\mathrm{x}_{\mathrm{Al}}$ in Equation (1) are too small to obviously affect the calculation of carbon content in RA, so the effects of $\mathrm{Mn}$ and $\mathrm{Al}$ concentrations on the carbon content in RA could be ignored normally.

According to the carbon content of RA and the contents of other alloy elements in as-rolled rail, the bainite transformation starting temperature (Bs), martensite transformation starting temperature (Ms) and time-temperature-transformation (TTT) curves of the RA for as-rolled rail were calculated using the JMatpro software [24] and the results are shown in Figure 9. The size of RA was very small and RA should contain many dislocations due to the displacive nature of bainite transformation. It is known that finer austenite is more stable than the larger one $[25,26]$. Besides, it is reported 
that intense dislocation debris around the bainite/austenite interface hinders the interface immobile and bainite transformation [27]. These microstructural characters of RA have strong influence on its stability. The microstructure effect was not considered during calculation. Therefore, the real bainite transformation kinetics should be slower than that of the calculated one (Figure 9a). Bs and Ms were $355{ }^{\circ} \mathrm{C}$ and $56{ }^{\circ} \mathrm{C}$, respectively. All tempering temperatures were higher than Ms, so that RA hardly decomposed into martensite during the tempering of the hot-rolled rail. In addition, tempering temperatures of $300{ }^{\circ} \mathrm{C}$ and $350{ }^{\circ} \mathrm{C}$ were below Bs, so that bainite transformation might occur at these temperatures. The TTT curve (Figure 9a) displays that the incubation period of bainite transformation at $300{ }^{\circ} \mathrm{C}$ is about $40 \mathrm{~min}$, which is shorter than the tempering time (200 $\left.\mathrm{min}\right)$, so that the bainite transformation can happen. Therefore, the decrease in RA amount after tempering at $300{ }^{\circ} \mathrm{C}$ and $350{ }^{\circ} \mathrm{C}$ was mainly caused by the decomposition of RA into bainite during tempering. It should be noted that carbon can diffuse from bainite ferrite and martensite into RA during tempering and bainite transformation, leading to the higher stability of RA. When the carbon content in RA reaches the $T_{0}$ curve (Figure 9b), at which the free energy of austenite equals that of ferrite, bainite transformation ceases [28]. Thus, only a part of RA transforms to bainite. When the tempering temperature was $400{ }^{\circ} \mathrm{C}$, there was no obvious carbide precipitation (Figure 5), so that the RA was too stable to decompose into other phases during tempering. As a result, the RA amount in the steel tempered at $400{ }^{\circ} \mathrm{C}$ was similar to that in the as-rolled steel. For tempering at high temperature $\left(500{ }^{\circ} \mathrm{C}\right)$, there were large amounts of fine carbides in the microstructure (Figure 6), which significantly decreased the stability of RA, so that almost all RA decomposed during tempering and there was no RA detected in XRD experiments (Figure 7).

As the tempering temperature increased, the carbon content in RA first increased and then decreased (Figure $8 b$ ). Compared with the as-rolled rail, the carbon content of RA in the tempered rail was larger due to the diffusion of carbon from bainite and martensite into austenite [23,24]. This means that the RA became more stable after tempering because the stability of RA was largely influenced by its carbon content. As the tempering temperature increased, there were two factors influencing the carbon content in RA. On the one hand, the diffusion of carbon into austenite increased its carbon content. On the other hand, carbide precipitation from austenite decreased its carbon content. When the tempering temperature was low (below $350{ }^{\circ} \mathrm{C}$ ), no carbides were formed (Figure 5), so that the carbon content of RA increased with the tempering temperature. However, when the tempering temperature was high (above $350{ }^{\circ} \mathrm{C}$ ), the carbon content decreased with the increase of tempering temperature, indicating that some very small carbides were formed during the tempering at $400{ }^{\circ} \mathrm{C}$ or higher temperature. It should be noted that it is difficult to observe carbides in TEM pictures for the specimens tempered at $400{ }^{\circ} \mathrm{C}$ and $450{ }^{\circ} \mathrm{C}$ due to the very small amount.
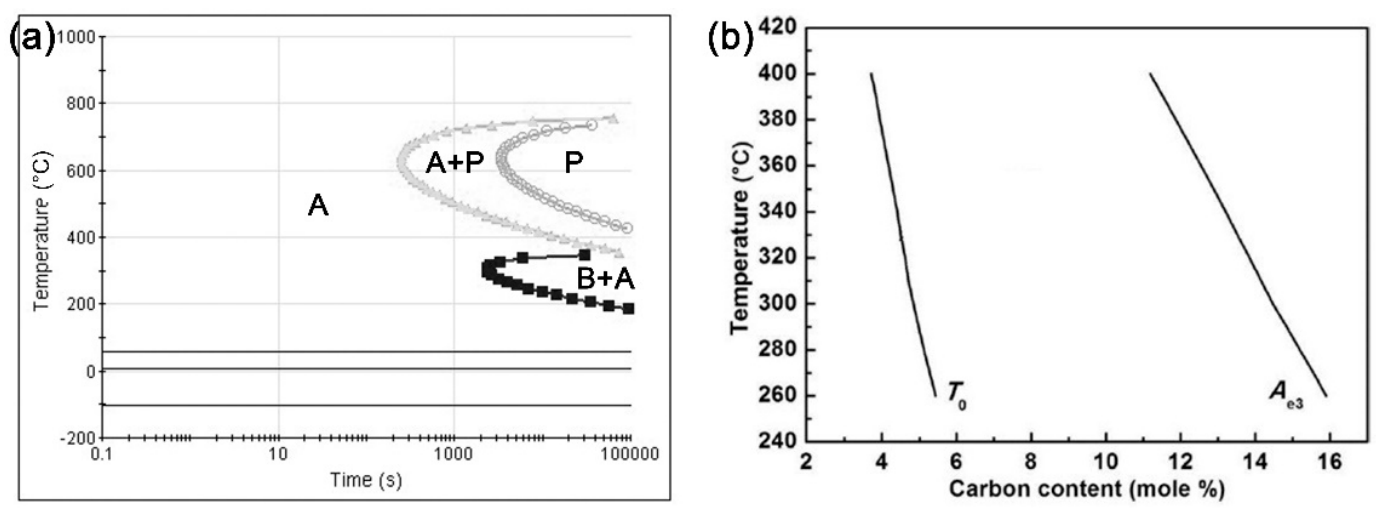

Figure 9. (a) TTT curves of the RA in as-rolled rail and (b) $T_{0}$ curve. 


\subsection{Mechanical Property}

Figure 10 presents the engineering stress-strain curves of the hot-rolled and tempered specimens. The tensile properties of the as-rolled and tempered rail heads are also shown in Figure 11 for clear comparison. The uncertainties in Figure 11 are standard deviations. The tensile strength of as-rolled bainite rail was about $1470 \mathrm{MPa}$ and the elongation was about $14.5 \%$, which were obviously superior to those of conventional pearlite rails. With the increase of tempering temperature from $300{ }^{\circ} \mathrm{C}$ to $450{ }^{\circ} \mathrm{C}$, the tensile strength decreased and the elongation increased. The high strength of bainite rail is mainly attributed to the ultra-fine bainite ferrite and high dislocation density in bainite ferrite. As the tempering temperature increased, the thickness of bainite ferrite slightly increased (Figure 4), the dislocation density in bainite ferrite decreased (Figure 4) and the carbon content in bainite ferrite decreased, so that the tensile strength decreased when the tempering temperature was below $450{ }^{\circ} \mathrm{C}$. However, when the tempering temperature was $450{ }^{\circ} \mathrm{C}$ and $500^{\circ} \mathrm{C}$, more carbides separated out from $\mathrm{M} / \mathrm{A}$ and bainite, which compensated for the decrease of strength, so the tensile strength of the bainite rail increased. In addition, the thickness of bainite ferrite increased and dislocation density decreased at the tempering temperature rose from $300{ }^{\circ} \mathrm{C}$ to $400{ }^{\circ} \mathrm{C}$, resulting in the increase of elongation compared to hot-rolled rail. Compared to the specimen tempered at $400{ }^{\circ} \mathrm{C}$, the elongation in the specimens tempered at $450{ }^{\circ} \mathrm{C}$ and $500{ }^{\circ} \mathrm{C}$ decreased due to carbide precipitation.

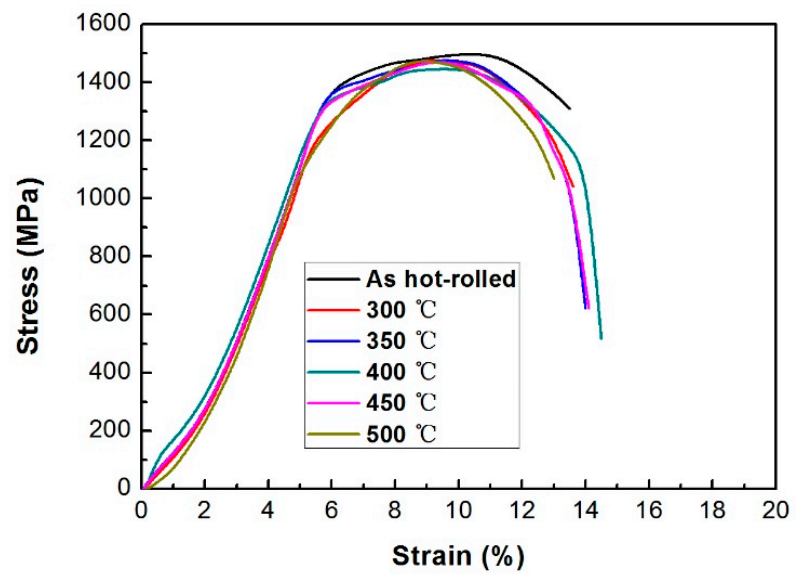

Figure 10. Engineering stress-strain curves for the hot-rolled and tempered specimens.
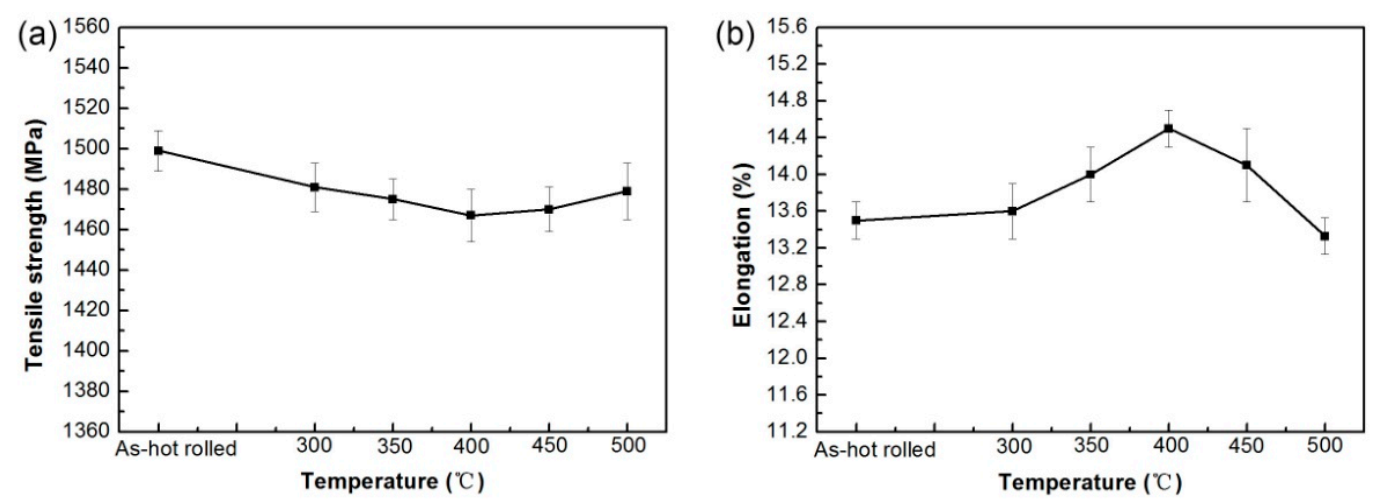

Figure 11. Tensile properties of rail head in as-rolled and tempered rails: (a) tensile strength; (b) elongation.

Figure 12 presents the impact toughness of the as-rolled and tempered rails. The impact toughness of as-rolled rail was about $41 \mathrm{~J} / \mathrm{cm}^{2}$. The impact toughness obviously increased to $65 \mathrm{~J} / \mathrm{cm}^{2} \mathrm{by}$ tempering at $300{ }^{\circ} \mathrm{C}$ due to the relief of residual stress and the increased stability of RA which 
improved the TRIP effect. The impact toughness reached $83 \mathrm{~J} / \mathrm{cm}^{2}$ when the tempering temperature was $400{ }^{\circ} \mathrm{C}$. However, when the tempering temperature increased to $450{ }^{\circ} \mathrm{C}$ and $500{ }^{\circ} \mathrm{C}$, the impact toughness of the rails significantly decreased, especially at $500{ }^{\circ} \mathrm{C}$. The toughness of the rail was only $12 \mathrm{~J} / \mathrm{cm}^{2}$ after tempering at $500{ }^{\circ} \mathrm{C}$, demonstrating a brittle fracture. Figure 13 depicts the diffraction peaks of the samples after the tensile test. It is obvious that the austenite peaks disappeared in all samples after the tensile test, indicating that RA decomposed during the tensile test. The RA was transformed to martensite during the tensile test and thus increased the plasticity and toughness of the steel, which is called the transformation-induced plasticity (TRIP) effect [21,29]. The appearance of platform in the stress-strain curves confirmed the TRIP effect. There was no apparent platform in the stress-strain curves of specimens tempered at $500{ }^{\circ} \mathrm{C}$, because almost all RA was decomposed during tempering at $500{ }^{\circ} \mathrm{C}$. There was no TRIP effect due to almost zero RA (Figure 8), resulting in obvious decrease in impact toughness. Besides, the large amount of carbide precipitation at $500{ }^{\circ} \mathrm{C}$ also decreased the toughness.

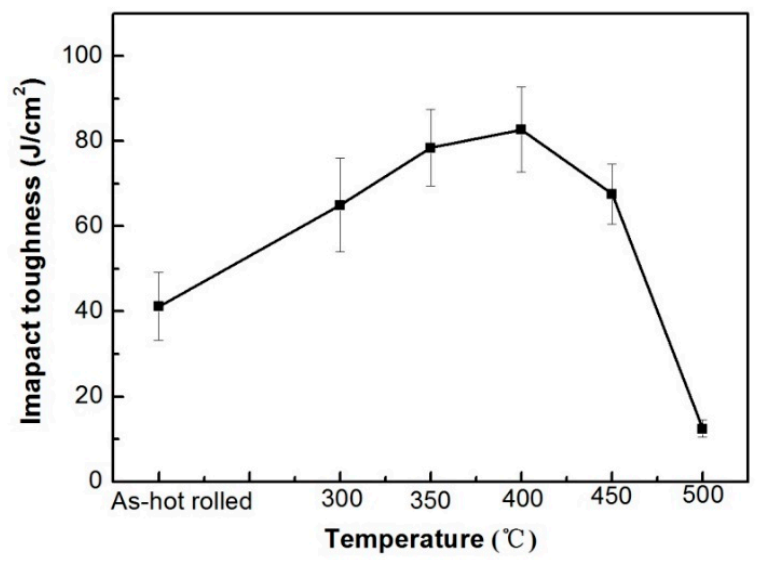

Figure 12. Impact toughness of as-rolled and tempered rails.

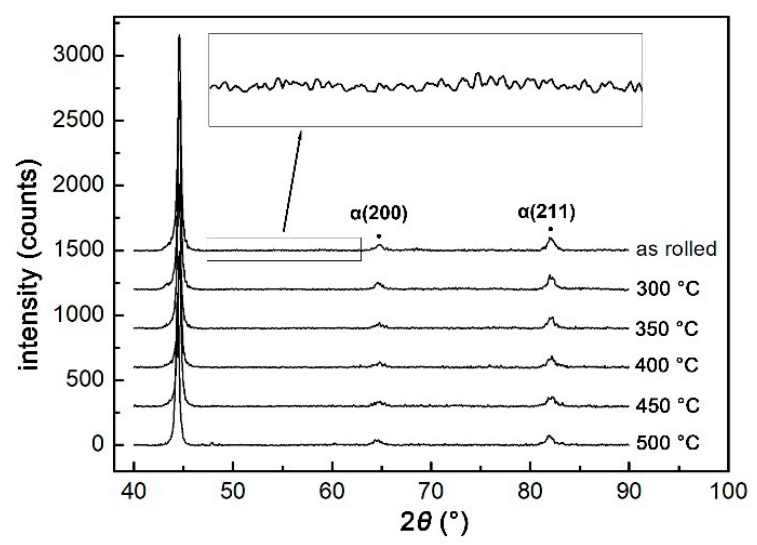

Figure 13. Diffraction peaks of different samples after tensile test.

Wang et al. [16] developed a tempered bainite rail steel with tensile strength of $1388 \mathrm{MPa}$ and elongation of $16 \%$. In the present study, a bainite rail with higher strength was developed. The tensile strength, elongation and impact toughness were about $1470 \mathrm{MPa}, 14.5 \%$ and $83 \mathrm{~J} / \mathrm{cm}^{2}$, respectively, after tempering at $400{ }^{\circ} \mathrm{C}$ for $200 \mathrm{~min}$. Therefore, a high-strength bainite rail with good toughness was developed in the present study. Compared to the steel in [16] $(0.22 \mathrm{C}-2.0 \mathrm{Mn}-1.0 \mathrm{Si}-0.8 \mathrm{Cr}-0.8(\mathrm{Mo}+\mathrm{Ni})$ $(\mathrm{wt} \%))$, the steel in the present work $(0.22 \mathrm{C}-1.5 \mathrm{Mn}-1.6 \mathrm{Si}-1.5 \mathrm{Cr}-0.41 \mathrm{Ni}-0.37 \mathrm{Mo}$ (wt \%)) contained more $\mathrm{Si}$ and $\mathrm{Cr}$ to suppress the formation of brittle cementite and obtain high-strength carbide-free bainite. In addition, the amount of RA in this work (maximum 15.5 vol \%) was much larger than 
that in [16] (maximum $\sim 8.8 \mathrm{vol} \%$ ), which also improved the mechanical properties of bainite steel by the TRIP effect. Moreover, the maximum tensile strength of conventional pearlite rail is below $1300 \mathrm{MPa}$ with inferior impact toughness. The mechanical property of the developed bainite rail is much superior to that of conventional pearlite rail.

\section{Conclusions}

An advanced bainite rail with high strength and good toughness was developed and produced in a steel mill. The tempering experiments were conducted and the effects of tempering on the microstructure and properties of the bainite rail were investigated. The following conclusions can be obtained:

(1) The tensile strength, elongation and the impact toughness were about $1470 \mathrm{MPa}, 14.5 \%$ and $83 \mathrm{~J} / \mathrm{cm}^{2}$, respectively, after tempering for $200 \mathrm{~min}$ at $400{ }^{\circ} \mathrm{C}$. A high-strength bainite rail steel with good toughness was developed.

(2) When the tempering temperature was lower than $400{ }^{\circ} \mathrm{C}$, the amount of RA decreased compared to the as-rolled rail due to the decomposition of austenite to bainite. At a middle tempering temperature of $400{ }^{\circ} \mathrm{C}$, the RA was very stable during tempering. When the tempering temperature was $500^{\circ} \mathrm{C}$, a large amount of carbides precipitated and RA almost disappeared.

(3) The tensile strength of the rail head decreased when the tempering temperature was lower than $450{ }^{\circ} \mathrm{C}$ due to the decreased dislocation density and carbon content in bainite ferrite and the coarseness of bainite ferrite. Carbide precipitation compensated for the decrease in strength when the tempering temperature was $450{ }^{\circ} \mathrm{C}$ and $500{ }^{\circ} \mathrm{C}$. In addition, the elongation slightly increased and impact toughness was obviously improved at the tempering temperature from $300{ }^{\circ} \mathrm{C}$ to $400{ }^{\circ} \mathrm{C}$. The impact toughness and elongation sharply decreased after tempering at $500{ }^{\circ} \mathrm{C}$ because of the appearance of carbides and absence of RA. Therefore, RA plays a significant role in the toughness of bainite rail by the TRIP effect.

Author Contributions: M.Z., doctoral student, conducted experiments, analyzed the data and wrote the paper; G.X., supervisor, conceived and designed the experiments; M.Z., doctoral students, conducted experiments and analyzed the data; Q.Y., doctoral students, conducted experiments and analyzed the data; J.T., doctoral students, conducted experiments and analyzed the data; H.H., doctoral students, conducted experiments and analyzed the data.

Funding: The Major Projects of Technological Innovation of Hubei Province (No. 2017AAA116), the National Natural Science Foundation of China (NSFC) (No. 51704217) and the National Natural Science Foundation of China (NSFC) (No. 51274154).

Conflicts of Interest: The authors declare no conflict of interest. The founding sponsors had no role in the design of the study; in the collection, analyses, or interpretation of data; in the writing of the manuscript, and in the decision to publish the results.

\section{References}

1. Yates, J.K. Innovation in rail steel. Sci. Parliam. 1996, 53, 2-3.

2. Debehets, J.; Tacq, J.; Favache, A.; Jacques, P.; Seo, J.W.; Verlinden, B.; Seefeldt, M. Analysis of the variation in nanohardness of pearlitic steel: Influence of the interplay between ferrite crystal orientation and cementite morphology. Mater. Sci. Eng. A 2014, 616, 99-106. [CrossRef]

3. Tan, Z.L.; An, B.F.; Gao, G.H.; Gui, X.L.; Bai, B.Z. Analysis of softening zone on the surface of 20Mn2SiCrMo bainitic railway switch. Eng. Fail. Anal. 2015, 47, 111-116. [CrossRef]

4. Caballero, F.G.; Bhadeshia, H.K.D.H. Very strong bainite. Curr. Opin. Solid State Mater. Sci. 2004, 8, $251-257$. [CrossRef]

5. Garcia-Mateo, C.; Caballero, F.G.; Bhadeshia, H.K.D.H. Development of hard bainite. ISIJ Int. 2003, 43, 1238-1243. [CrossRef]

6. Zhou, M.X.; Xu, G.; Hu, H.J.; Yuan, Q.; Tian, J.Y. Comprehensive analysis on the effects of different stress states on the bainitic transformation. Mater. Sci. Eng. A 2017, 704, 427-433. [CrossRef] 
7. Long, X.Y.; Kang, J.; Lv, B.; Zhang, F.C. Carbide-free bainite in medium carbon steel. Mater. Des. 2014, 64, 237-245. [CrossRef]

8. Zhou, M.X.; Xu, G.; Hu, H.J.; Yuan, Q.; Tian, J.Y. Kinetics model of bainitic transformation with stress. Met. Mater. Int. 2018, 24, 28-34. [CrossRef]

9. Tian, J.Y.; Xu, G.; Zhou, M.X.; Hu, H.J.; Wan, X.L. The effects of $\mathrm{Cr}$ and $\mathrm{Al}$ addition on transformation and properties in low-carbon bainitic steels. Metals 2017, 7, 40. [CrossRef]

10. Hu, H.J.; Xu, G.; Wang, L.; Xue, Z.L.; Zhang, Y.L.; Liu, G.H. The effects of Nb and Mo addition on transformation and properties in low carbon bainitic steels. Mater. Des. 2015, 84, 95-99. [CrossRef]

11. Zhou, M.X.; Xu, G.; Tian, J.Y.; Hu, H.J.; Yuan, Q. Bainitic transformation and properties of low carbon carbide-free bainitic steels with $\mathrm{Cr}$ addition. Metals 2017, 7, 263. [CrossRef]

12. Vorozhishchev, V.I.; Pavlov, V.V.; Kornieva, L.V. Production of bainite steel rails. Steel Transl. 2005, 35, 66-70.

13. Aglan, H.A.; Liu, Z.Y.; Hassan, M.F.; Fateh, M. Mechanical and fracture behavior of bainitic rail steel. J. Mater. Process. Technol. 2004, 151, 268-274. [CrossRef]

14. Lee, K.M.; Polycarpou, A. Wear of conventional pearlitic and improved bainitic rail steels. Wear 2005, 259, 391-399. [CrossRef]

15. Li, Y.G.; Zhang, F.C.; Chen, C.; Lv, B.; Yang, Z.N.; Zheng, C.L. Effects of deformation on the microstructures and mechanical properties of carbide-free bainitic steel for railway crossing and its hydrogen embrittlement characteristics. Mater. Sci. Eng. A 2016, 651, 945-950. [CrossRef]

16. Wang, K.K.; Tan, Z.L.; Gao, G.H.; Gui, X.L.; Misra, R.D.K.; Bai, B.Z. Ultrahigh strength-toughness combination in Bainitic rail steel: The determining role of austenite stability during tempering. Mater. Sci. Eng. A 2016, 662, 162-168. [CrossRef]

17. Wang, K.K.; Tan, Z.L.; Gao, G.H.; Gui, X.L.; Bai, B.Z. Effect of retained austenite stability on mechanical properties of bainitic rail steel. Adv. Mater. Res 2014, 1004-1005, 198-202. [CrossRef]

18. Gui, X.L.; Wang, K.K.; Gao, G.H.; Misra, R.D.K.; Tan, Z.L.; Bai, B.Z. Rolling contact fatigue of bainitic rail steels: The significance of microstructure. Mater. Sci. Eng. A 2016, 657, 82-85. [CrossRef]

19. Zhang, F.C.; Zheng, C.L.; Lv, B.; Wang, T.S.; Li, M.; Zhang, M. Effects of hydrogen on the properties of bainitic steel crossing. Eng. Fail. Anal. 2009, 16, 1461-1467. [CrossRef]

20. Zhou, M.X.; Xu, G.; Wang, L.; Hu, H.J. Combined effect of the prior deformation and applied stress on the bainite transformation. Met. Mater. Int. 2016, 22, 956-961. [CrossRef]

21. Garcia-Mateo, C.; Caballero, G.F. The role of retained austenite on tensile properties of steels with bainitic microstructures. Mater. Trans. 2005, 46, 1839-1846. [CrossRef]

22. Wang, C.Y.; Shi, J.; Cao, W.Q.; Dong, H. Characterization of microstructure obtained by quenching and partitioning process in low alloy martensitic steel. Mater. Sci. Eng. A 2010, 527, 3442-3449. [CrossRef]

23. Hasan, H.S.; Peet, M.J.; Avettand-Fènoël, M.N.; Bhadeshia, H.K.D.H. Effect of tempering upon the tensile properties of a nanostructured bainitic steel. Mater. Sci. Eng. A 2014, 615, 340-347. [CrossRef]

24. Hou, Z.Y.; Babu, R.P.; Hedström, P.; Odqvist, J. Microstructure evolution during tempering of martensitic Fe-C-Cr alloys at $700{ }^{\circ}$ C. J. Mater. Sci. 2018, 53, 6939-6950. [CrossRef]

25. Bai, D.Q.; Chiro, A.D.; Yue, S. Stability of Retained Austenite in a Nb Microalloyed Mn-Si TRIP Steel. In Materials Science Forum; Trans Tech Publications: Zürich, Switzerland, 1998; Volumes 284-286, pp. $253-262$.

26. Garcia-Mateo, C.; Caballero, F.G.; Chao, J.; Capdevila, C.; Andres, C.G.D. Mechanical stability of retained austenite during plastic deformation of super high strength carbide free bainitic steels. J. Mater. Sci. 2009, 44, 4617-4624. [CrossRef]

27. Chatterjee, S.; Wang, H.S.; Yang, J.R.; Bhadeshia, H.K.D.H. The mechanical stabilisation of austenite. Mater. Sci. Technol. 2006, 22, 641-644. [CrossRef]

28. Caballero, F.G.; Santofimia, M.J.; García-Mateo, C.; Chao, J.; García de Andrés, C. Theoretical design and advanced microstructure in super high strength steels. Mater. Des. 2009, 30, 2077-2083. [CrossRef]

29. Cooman, B.C.D. Structure-properties relationship in TRIP steels containing carbide-free bainite. Curr. Opin. Solid State Mater. Sci. 2004, 8, 285-303. [CrossRef]

(C) 2018 by the authors. Licensee MDPI, Basel, Switzerland. This article is an open access article distributed under the terms and conditions of the Creative Commons Attribution (CC BY) license (http:/ / creativecommons.org/licenses/by/4.0/). 